\title{
Predicting Loyalty in Malaysian Public Higher Education using Theory of Planned Behaviour
}

\author{
Helmie Sheha Che Azemi ${ }^{1}$, Abdul Rahim Romle ${ }^{2}$, \\ ${ }^{1,2}$ Universiti Utara Malaysia \\ ${ }^{1}$ helmiesheha11@gmail.com \\ 2abd.rahim@uum.edu.my
}

\begin{tabular}{l}
\hline ARTICLEDETAILS \\
\hline History : \\
Received : \\
Revised/Format : \\
Accepted : \\
\hline
\end{tabular}

Keywords : intentional behavior, loyalty, theory of planned behaviour, higher education

\begin{abstract}
S
Most of studies in business and marketing are adopting various theories to understand loyalty among customers. In the recent studies, understanding customer behaviour will help institutions to re-strategize their planning and operations to increase students' enrolment and retention. Hence, the purpose of this study is to examine the combined factors of attitude, subjective norms, perceived behavioural control and brand loyalty which mediated by intention to loyal and fill in the gap of literature pertaining brand loyalty. The application of Theory of Planned Behaviour (TPB) has been widely used to measure individual's behaviour, and therefore, this study is intended to adopt TPB in understanding factors that influence loyalty in higher education. The findings in this study will help to provide more explanations and insight about students' behaviour and their loyalty simultaneously will benefit the university managers to improve their future marketing strategy of HEIs.
\end{abstract}

(C2020 STIM Lasharan Jaya Makassar

\section{INTRODUCTION}

From the rapid changing of the modern world, the universities around the world are resolutely becoming dynamic in term of building customer relationship. The emerging universities across the countries, higher education institutions are demanded to generate a continuous revenue for future sustainability. Apparently, the intense competition among universities and cost-cutting of government funding are becoming push factors of tertiary educational institutions to focus on improving their service quality and image. For instance, the delivering better service quality will enhance the academic institutions reputation as well as increasing their ranking.

Inevitably, the international students are recognized as significant element in higher education institutions as a source of contribution from tuition fees and miscellaneous payment of services. This dependency has insisted most of universities to adopt a good model of student retention and winning their heart to become loyal. In fact, several studies have attempted to identified factors that influenced student loyalty. However, certain area is still in lack of understanding. Previous research such in the study of Ali, Zhou, Hussain, Nair and Ragavan (2016) identify that service quality has significantly influenced on students' satisfaction, institutional image and their loyalty. While Ismanova (2019) found the significant relationship between perceived service quality and loyalty through the mediation of satisfaction and commitment. Hence, Shahsavar and Sudzina (2017) suggest that educational service should identify influential factors to improve students' satisfaction and their intention to become loyal to the institutions. Through the cognitive perspective, satisfied students feel more attached to their universities and sharing their experiences with others. Therefore, we 
want to extend the effort from previous studies in corporating Theory of Planned Behaviour in understanding student loyalty in higher education.

The growing number of studies using Theory of Planned Behavior were mainly focusing on consumer behaviour especially in psychology (Lac, Crano, Berger and Alvaro, 2013; Sahban, M., \& Ramalu, 2014; Prapvessis, Gaston and DeJesus, 2015), green consumerism (Hsu, Chang and Yansritakul, 2017), health (Lao, Tao and Wu, 2016; Siuki, Peyman, VahedianShahroodi, Gholian-Aval \& Tehrani, 2019) and little less in predicting customer behaviour especially in higher educations. Thus, this paper attempts to adopt TPB in explaining the customers' decision making process especially in the public Malaysian higher education. Dewberry and Jackson (2018) in their first attempt to study on the students' intention to leave the college. The result of the study showed that Theory of Planned Behaviour has predicted the students' intention to drop out. To further understand the psychological behaviour on students' intentional behavior, the main focus of this study is to examine the impact of Theory of Planned Behaviour on student loyalty in higher education with the objectives are as follows:

a. To examine the relationship between attitude, subjective norms, perceived behavioral control and intentional behaviour

b. To investigate the relationship between intentional behavior and loyalty

\section{LITERATURE REVIEW}

\section{Loyalty in Higher Education}

When choosing on certain brands, customer always have preferences and they are likely to select the brands that they are like the most. The unique offering of certain brands and service customization clearly build the customers' trust. In the other way around, their loyalty turned into the asset that is profitable to the company. The loyal customers are emotionally engaged to the brand (Park, MacInnis, Priester, Eisingerich and Iacobucci, 2010). Hence, brand loyalty is a display of a behaviour pattern as a result from the attitude and commitment of customer to repeat purchase on particular products and services (Dick and Basu, 1992). Therefore, gaining customer loyalty is much more important for a company to stay survive and stay in the stream of competition from other businesses. The plethora of researches found significant findings on customer loyalty and its antecedents (Kim, Wong, Chang \& Park, 2016; Kiran \& Diljit, 2017; Martinez, 2015; Nyadzayo \& Khajehzadeh, 2016; Watson, Beck, Henderson \& Palmatier, 2015). Although the quality factors are essential to customer attitudinal and behavioural action towards brand, customer behaviour is also important to be observed. The decision to remain loyal or not is also matter based on customers' experience with the brands (Ewing, 2000). Oliver (1997) mentioned that customers' true loyalty is based on the stages from cognitive loyalty to affective loyalty which later showing tendency into conative loyalty and finally transform into behavioural loyalty.

Although the educational services also can be identified as business offerings, the concept of loyalty in higher education is not well defined (Ali, Zhou, Hussain, Nair \& Ragavan, 2016; Rojaz-Mendez, Vasquez-Parraga, Kara \& Cerda-Urrutia, 2009). Some scholars associated dimensions as quality (Chen, 2016; Ali et al., 2016) perceived value (Carvalho \& Oliveira, 2010; Sampaio, Perin, Simoes \& Kleinowski, 2012) and any other determinants of loyalty in higher education, however the prediction of students' intention to loyal is still in underserved area of understanding. To date, there scant of research that considering cognitive aspect to loyalty especially in higher education.

\section{Theory of Planned Behavior in Predicting Loyalty}

Theory of Planned Behavior was developed to understand the complexity of human behaviour. It is further explained through the context of behavioral intentions are influenced 
by the perceptions or expectations of performing the behaviour. Ajzen (2006) emphasizes that human behaviour explain a wide range of health behaviors and intentions including smoking, drinking, health services utilization, breastfeeding, and substance use, among others. Some experts state that behavioral achievement depends on both intention and behavioral control. It distinguishes between three types of beliefs - behavioral, normative, and control. Ha (1998) argues that numerous of studies only measured on the behavioural aspects and there little that considering cognitive aspects. Hartel and Russell-Bennett (2010) also argue the function of emotional and cognitive loyalty which determine the consumer future continuation of purchase.

This study will adopt the three components of Theory of Planned Behaviour from Ajzen (1991) combining with variables from previous current studies. The components of TPB are include attitude, subjective norms and perceived behavioural control which elaborated as below;

\section{Attitude}

Traditionally, attitude is a form of cognitive aspect that involves a set belief to encourage someone to be or not to be (Ajzen \& Fishbein, 1977). Lee and Ullah (2011) stated that attitude is a set of judgment which allow customers to choose type of services which is satisfy them. Khare (2011) added that attitude can be also influenced by perceived benefits and value if they choose to act rightly. As rightly defined by Ajzen (1991) attitude are connected to the positive or negative evaluation to perform behavior and it has strong connection with behavioral belief as the indication on performing the act (Ajzen, 2002). Khalek (2014) found significant relationship between attitude and customer behavioural intention to buy halal food. Similarly in the finding by Kim and Yoon (2017) also found a significant customer attitude in buying green product. Thus, we hypothesized as following;

\section{H1: There is a positive relationship between attitude and intention to loyal}

\section{Subjective Norms}

Subjective norms is related to the social influences on individuals in favor to do or not to do certain things that normally accepted or not by others (Ajzen, 1991). It is about the set of beliefs by individuals that is in line with others perspectives and can be accepted by their groups for such act performed. Back then, there are abundant of studies have been made to examine the effect of subjective norms on consumers' behavior. For example, social pressure on certain individual will influence their attitude towards behavioral intention in purchasing (Ming-Shen, Chih-Chung, Su-Chao \& Yung-Her, 2007; Tarkiainen \& Sundqvist, 2005). Hübner and Kaiser (2006) refer to the uncertainty of subjective norms to influence the intention that may depends on certain situations. When it comes to decision making, consumer always have second opinion either to buy or not after getting several opinions from family and friends. In higher education for example, the influence of parents in selecting the right place for their children to study is also contributing to students' decision making. Therefore, we hypothesized as following;

\section{H2: There is a positive relationship between subjective norms and intention to loyal}

\section{Perceived Behavioral Control}

In the concept of perceived behavioral control, Ajzen (2002) has presented that it is a form of control beliefs on perceived of ease or difficulty to perform. Primarily, it is also being related to self-efficacy (Ajzen, 2002), and as explained by Bandura (1977) as choice made by customers by giving the whole commitment and perseverance on performing act to engage 
with the services. Moreover, self-efficacy is more about willingness to act or not to act. It also give the option to individuals to decide the strength of ability on performing task and durability to stay stable and always looking forward to complete their goals. The stronger of self-efficacy, the high of ability to endure and vice versa (Bandura, 1977). To explain in details, self-efficacy beliefs is a cognitive process that blooming in many ways. People are whether direct or indirectly aware that their mind always be on setting which is purposive, often influenced by forethought that targeting on their goal. When one's goal setting is influenced by self-appraisal of capabilities (Bandura, 1993), the stronger they will adhered to perform or to achieve it (Bandura, 1991). Previous study has found perceived behavioural control as significant predictor to behavioural intention (Dutta \& Singh, 2014; Johe \& Bhullar, 2016). Therefore, we hypothesized as following;

H3: There is a positive relationship between perceived behavioural control and intention to loyal

\section{Intention to Loyal}

Customers' intention to buy always become the predictor of the actual behaviour of purchasing a product. Ajzen and Fishbein (1977) agree that the consumers' purchase intention is an essential index to predict consumer behaviour as a subjective attachment to the product and services. Liu-Thompkins and Tam (2013) add that not all repeat customers do buy same brand can be considered as attitudinal loyalty but it is also because their habit in buying too. They do emphasize that repeat purchase are involving behavioural patterns and motivated by both attitudinal and habit. The intention of repeat purchasing captures the loyalty of a consumer towards the products, services or brands of interest (Oliver, 1999). Customer with high psychological attachment to a brand are fully committed to stick to the same brand even they have many options to choose same product produced by different company (Yim \& Kannan, 1999). Apart from that, consumers' purchase intention also serves as a mediator between their attitude towards a special product and their real purchase behaviour (Ajzen \& Fishbein, 1977). Some studies have supported the finding that intentional behaviour lead to actual behaviour (Ho, Wu, Nguyen \& Chen, 2019; Kassim, Arokiasamy \& Ping, 2019; Shahid Iqbal, Ul Hassan \& Habibah, 2018) Thus, it is hypothesized that;

H4: There is positive relationship between intention to loyal and loyalty

\section{CONCLUSIONS}

The higher education institutions especially have face stronger competition among universities around the world and it has urge them to provide services that fulfill students' requirements and expectations. Exploring the elements that positively influence behavioural intentions such as attitude, subjective norms and perceived behavioural control and the link to brand loyalty, this study will contribute to the existing literatures on customer loyalty. Indeed, it also will help the university managers to focus

Previous studies have developed different models that theorise on customer loyalty ( $\mathrm{Fu}$, Zhang \& Chan, 2018; Luarn and Lin, 2003; Mohamad, Ab Yazid, Khatibi and Azam, 2017). However, the application of TPB in measuring loyalty especially in higher education has not been associated in the previous study. Therefore, a conceptual model developed in this study is based on the constructs adopted from Theory of Planned Behaviour and proposed as below; 


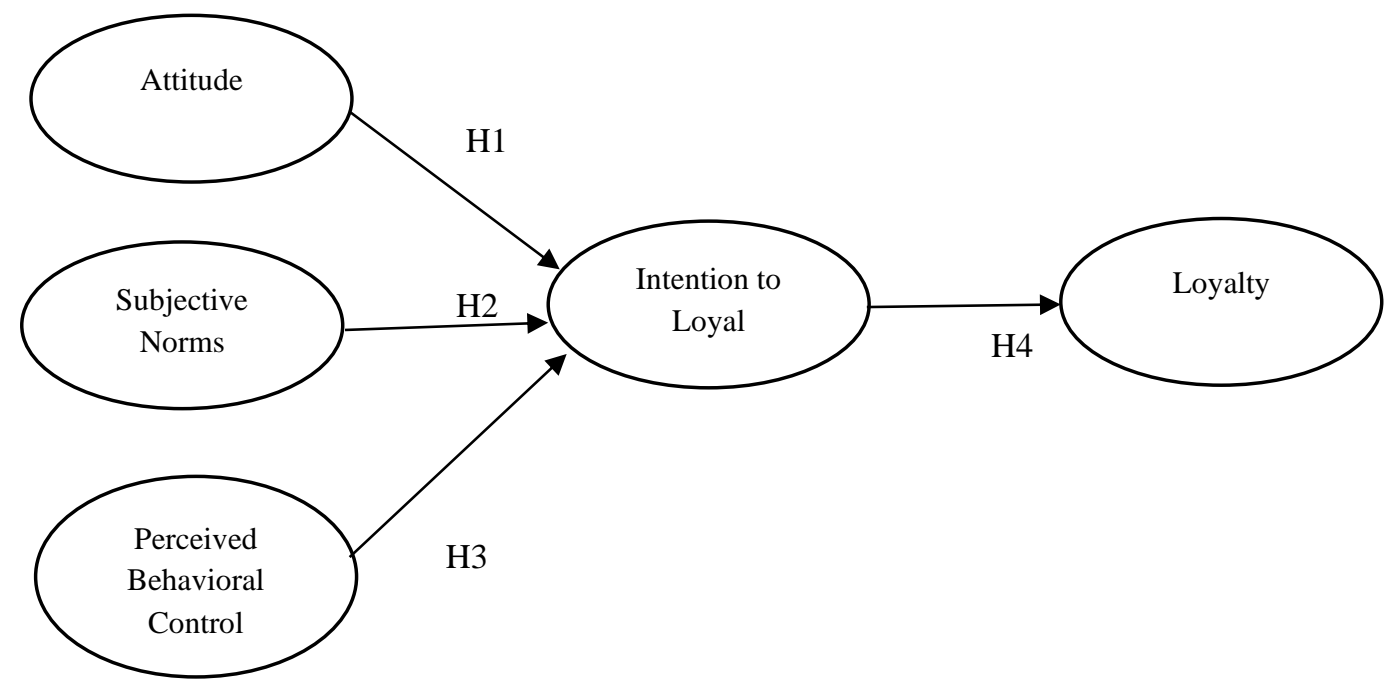

Figure 1: Theoretical framework of this study

The conceptualization of brand loyalty in this paper provides an academic insights that is still lacking in previous studies. With the varying approaches on identifying customer loyalty, this model can be served as a guideline for higher educations to understand their customers' need. Moreover, it helps to understand their customer better and satisfy them and therefore creates more opportunities to build loyalty.

\section{REFERENCES}

Ajzen, I. (1991). The theory of planned behavior. Organizational behavior and human decision processes, 50(2), 179-211.

Ajzen, I. (2006). Constructing a theory of planned behavior questionnaire: Conceptual and methodological considerations. Retrieved September, 15, 2015.

Ajzen, I., \& Fishbein, M. (1977). Attitude-behavior relations: A theoretical analysis and review of empirical research. Psychological bulletin, 84(5), 888.

Al Mamun, A., Mohamad, M. R., Yaacob, M. R. B., \& Mohiuddin, M. (2018). Intention and behavior towards green consumption among low-income households. Journal of environmental management, 227, 73-86.

Ali, A., Xiaoling, G., Sherwani, M., \& Ali, A. (2017). Factors affecting Halal meat purchase intention: Evidence from international Muslim students in China. British Food Journal, 119(3), 527-541.

Ali, F., Zhou, Y., Hussain, K., Nair, P. K., \& Ragavan, N. A. (2016). Does higher education service quality effect student satisfaction, image and loyalty?. Quality assurance in education.

Bandura, A. (1977). Self-efficacy: toward a unifying theory of behavioral change. Psychological review, 84(2), 191.

Bandura, A. (1982). The assessment and predictive generality of self-percepts of efficacy. Journal of behavior therapy and experimental psychiatry, 13(3), 195-199.

Bandura, A. (1991). Social cognitive theory of self-regulation. Organizational behavior and human decision processes, 50(2), 248-287.

Bandura, A. (1993). Perceived self-efficacy in cognitive development and functioning. Educational psychologist, 28(2), 117-148.

Bandura, A., Adams, N. E., Hardy, A. B., \& Howells, G. N. (1980). Tests of the generality of self-efficacy theory. Cognitive therapy and research, 4(1), 39-66. 
Browne, B. A., Kaldenberg, D. O., Browne, W. G., \& Brown, D. J. (1998). Student as customer: Factors affecting satisfaction and assessments of institutional quality. Journal of Marketing for Higher Education, 8(3), 1-14.

Carvalho, S. W., \& Oliveira, M. M. D. (2010). The role of trust in creating value and student loyalty in relational exchanges between higher education institutions and their students. Journal of marketing for higher education, 20(1), 145-165.

Chen, Y. C. (2016). The drive behind international student loyalty in higher-educational institutions: a structural equation model. The Asia-Pacific Education Researcher, 25(2), 315-323.

Chew, B. E., \& Adis, A. A. A. (2018). A Study on Malaysian Consumers' Attitude and Behavioral Intention Towards Print Advertising. International Journal of Marketing Studies, 10(2), 132-150.

Dewberry, C., \& Jackson, D. J. (2018). An application of the theory of planned behavior to student retention. Journal of Vocational Behaviour, 107, 100-110.

Dick, A. S., \& Basu, K. (1994). Customer loyalty: toward an integrated conceptual framework. Journal of the academy of marketing science, 22(2), 99-113.

Dutta, K., \& Singh, S. (2014). Applying the Theory of Planned Behavior to Understand Indian Housewives' Purchase Behavior Towards Healthy Food Brands. IUP Journal of Brand Management, 11(4).

Ewing, M. T. (2000). Brand and retailer loyalty: past behavior and future intentions. Journal of Product \& Brand Management.

Fu, X. M., Zhang, J. H., \& Chan, F. T. (2018). Determinants of loyalty to public transit: A model integrating Satisfaction-Loyalty Theory and Expectation-Confirmation Theory. Transportation Research Part A: Policy and Practice, 113, 476-490.

Hair Jr, J. F., Money, A. H., Samouel, P., \& Page, M. (2007). Research Methods for Business. John Wiley \& Sons.". Ltd. USA.

Härtel, C. E., \& Russell-Bennett, R. (2010). Heart versus mind: The functions of emotional and cognitive loyalty. Australasian Marketing Journal (AMJ), 18(1), 1-7.

Ho, T. N., Wu, W. Y., Nguyen, P. T., \& Chen, H. C. (2019). The Moderating Effects for the Relationships between Green Customer Value, Green Brand Equity and Behavioral Intention. Academy of Strategic Management Journal.

Hsu, C. L., Chang, C. Y., \& Yansritakul, C. (2017). Exploring purchase intention of green skincare products using the theory of planned behavior: Testing the moderating effects of country of origin and price sensitivity. Journal of Retailing and Consumer Services, 34, 145-152.

Hübner, G., \& Kaiser, F. G. (2006). The moderating role of the attitude-subjective norms conflict on the link between moral norms and intention. European Psychologist, 11(2), 99-109.

Hung, Y., de Kok, T. M., \& Verbeke, W. (2016). Consumer attitude and purchase intention towards processed meat products with natural compounds and a reduced level of nitrite. Meat science, 121, 119-126.

Ismanova, D. (2019). Students' loyalty in higher education: The mediating effect of satisfaction, trust, commitment on student loyalty to Alma Mater. Management Science Letters, 9(8), 1161-1168.

Johe, M. H., \& Bhullar, N. (2016). To buy or not to buy: The roles of self-identity, attitudes, perceived behavioral control and norms in organic consumerism. Ecological Economics, 128, 99-105.

Kashif, M., \& Cheewakrakokbit, P. (2018). Perceived service quality-loyalty path: A PAKSERV based investigation of international students enrolled in business schools in Thailand. Journal of Marketing for Higher Education, 28(1), 51-65.

Kassim, K. A. A., Arokiasamy, L., \& Ping, C. H. (2019). Intention to Purchase Safer Car in Indonesia: An Application of Theory of Planned Behaviour. Global Business \& Management Research, 11(1).

Khalek, A. A. (2014). Young consumers' attitude towards halal food outlets and JAKIM's halal certification in Malaysia. Procedia-Social and Behavioral Sciences, 121(1), 2634. 
Khalek, A. A. (2014). Young consumers' attitude towards halal food outlets and JAKIM's halal certification in Malaysia. Procedia-Social and Behavioral Sciences, 121(1), 2634

Khalek, A. A., Ismail, S. H. S., \& Ibrahim, H. M. (2017). A Study On The Factors Influencing Young Muslims'behavioral Intention In Consuming Halal Food In Malaysia. Jurnal Syariah, 23(1), 79-102.

Khare, A. (2011). Customers' perception and attitude towards service quality in multinational banks in India. International Journal of Services and Operations Management, 10(2), 199-215.

Kim, M. K., Wong, S. F., Chang, Y., \& Park, J. H. (2016). Determinants of customer loyalty in the Korean smartphone market: Moderating effects of usage characteristics. Telematics and Informatics, 33(4), 936-949.

Kim, Y. J., \& Yoon, H. J. (2017). Predicting green advertising attitude and behavioral intention in South Korea. Social Behavior and Personality: an international journal, 45(8), 1345-1364.

Kiran, K., \& Diljit, S. (2011). Antecedents of customer loyalty: Does service quality suffice. Malaysian Journal of Library \& Information Science, 16(2), 95-113.

Kitchenham, B., \& Pfleeger, S. L. (2002). Principles of survey research: part 5: populations and samples. ACM SIGSOFT Software Engineering Notes, 27(5), 17-20.

Lac, A., Crano, W. D., Berger, D. E., \& Alvaro, E. M. (2013). Attachment theory and theory of planned behavior: An integrative model predicting underage drinking. Developmental psychology, 49(8), 1579.

Lao, H. C., Tao, V. Y., \& Wu, A. M. (2016). Theory of planned behaviour and healthy sleep of college students. Australian Journal of Psychology, 68(1), 20-28.

Lee, K. H., \& Ullah, S. (2011). Customers' attitude toward Islamic banking in Pakistan. International Journal of Islamic and Middle Eastern Finance and Management, 4(2), 131-145.

Liu-Thompkins, Y., \& Tam, L. (2013). Not all repeat customers are the same: Designing effective cross-selling promotion on the basis of attitudinal loyalty and habit. Journal of Marketing, 77(5), 21-36.

Luarn, P., \& Lin, H. H. (2003). A customer loyalty model for e-service context. J. Electron. Commerce Res., 4(4), 156-167.

Martínez, P. (2015). Customer loyalty: exploring its antecedents from a green marketing perspective. International Journal of Contemporary Hospitality Management, 27(5), 896-917.

Ming-Shen, W., Chih-Chung, C., Su-Chao, C., \& Yung-Her, Y. (2007). Effects of online shopping attitudes, subjective norms and control beliefs on online shopping intentions: A test of the theory of planned behaviour. International Journal of Management, 24(2), 296.

Mohamad, H. A. D., Ab Yazid, M. S., Khatibi, A., \& Azam, S. F. (2017). Service quality, customer satisfaction and customer loyalty of the hotel industry in United Arab Emirates (UAE): A measurement model. European Journal of Management and Marketing Studies.

Nyadzayo, M. W., \& Khajehzadeh, S. (2016). The antecedents of customer loyalty: A moderated mediation model of customer relationship management quality and brand image. Journal of Retailing and Consumer Services, 30, 262-270.

Oliver, R. L. (1999). Whence consumer loyalty? the Journal of Marketing, 33-44.

Park, C.W., MacInnis, D. J., Priester, J., Eisingerich, A. B., \& Iacobucci, D. (2010). Brand attachment and brand attitude strength: Conceptual and empirical differentiation of two critical brand equity drivers. Journal of marketing, 74(6), 1-17.

Prapavessis, H., Gaston, A., \& DeJesus, S. (2015). The theory of planned behavior as a model for understanding sedentary behavior. Psychology of Sport and Exercise, 19, 23-32.

Rojas-Méndez, J. I., Vasquez-Parraga, A. Z., Kara, A. L. I., \& Cerda-Urrutia, A. (2009). Determinants of student loyalty in higher education: A tested relationship approach in Latin America. Latin American Business Review, 10(1), 21-39. 
Sahban, M. A., M., D. K., \& Ramalu, S. S. (2014). Categorizing and Fixing Variables on Entrepreneurial Intention through Qualitative Research. Asian Social Science, 10(19), 45-59. https://doi.org/10.5539/ass.v10n19p45

Sampaio, C. H., Perin, M. G., Simões, C., \& Kleinowski, H. (2012). Students' trust, value and loyalty: evidence from higher education in Brazil. Journal of Marketing for Higher Education, 22(1), 83-100.

Shahid Iqbal, M., Ul Hassan, M., \& Habibah, U. (2018). Impact of self-service technology (SST) service quality on customer loyalty and behavioral intention: The mediating role of customer satisfaction. Cogent Business \& Management, 5(1), 1.

Shahsavar, T., \& Sudzina, F. (2017). Student satisfaction and loyalty in Denmark: Application of EPSI methodology. PloS one, 12(12).

Siuki, H. A., Peyman, N., Vahedian-Shahroodi, M., Gholian-Aval, M., \& Tehrani, H. (2019). Health education intervention on HIV/AIDS prevention behaviors among health volunteers in healthcare centers: An applying the theory of planned behavior. Journal of Social Service Research, 45(4), 582-588.

Snijders, I., Wijnia, L., Rikers, R. M., \& Loyens, S. M. (2019). Alumni loyalty drivers in higher education. Social Psychology of Education, 22(3), 607-627.

Tarkiainen, A., \& Sundqvist, S. (2005). Subjective norms, attitudes and intentions of Finnish consumers in buying organic food. British food journal, 107(11), 808-822.

Watson, G. F., Beck, J. T., Henderson, C. M., \& Palmatier, R. W. (2015). Building, measuring, and profiting from customer loyalty. Journal of the Academy of Marketing Science, 43(6), 790-825.

Wood, R., \& Bandura, A. (1989). Social cognitive theory of organizational management. Academy of management Review, 14(3), 361-384.

Yim, C. K., \& Kannan, P. K. (1999). Consumer behavioral loyalty. Journal of business research, 44(2), 75-92. 